\title{
A rare case of bilateral aldosterone producing adrenal masses with concurrent bilateral renal cell carcinoma and multiple benign neoplasia
}

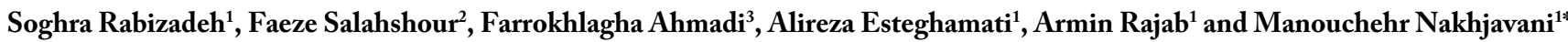 \\ ${ }^{1}$ Endocrinology and Metabolism Research Center (EMRC), Vali-Asr Hospital, Tehran University of Medical Sciences, Tehran, Iran \\ ${ }^{2}$ Department of radiology, Tehran University of Medical Sciences, Tehran, Iran \\ ${ }^{3}$ Nephrology Research Center, Imam Khomeni Hospital, Tehran University of Medical Sciences, Tehran, Iran
}

\begin{abstract}
Introduction: Primary aldosteronism (PA) is the most common form of secondary hypertension. It can be either cured or treated with surgery or medical therapy. Current estimation of the prevalence of Primary aldosteronism is $5-10 \%$ of all hypertensive patients. Here we presented a patient with a history of long-standing hypertension and co-incidence of renal cell carcinoma, thyroid nodules, benign prostatic hyperplasia and final diagnosis of primary hyperaldosteronism due to bilateral adrenal masses. We briefly described the mechanisms involved in the association of primary aldosteronism and renal cell carcinoma.

Case presentation: A 71-year-old man, with a history of hypertension from 30 years ago was evaluated for uncontrolled hypertension and hypokalemia. Also, he had a history of renal cell carcinoma and benign prostatic hyperplasia 2 years ago. Plasma aldosterone and renin activity were measured after correction of hypokalemia. Primary aldosteronism was diagnosed based on high aldosterone to renin ratio and bilateral adrenal masses in the abdominal CT scan. Moreover, we found benign thyroid nodules in the examination and fine needle aspiration. The patient treated with eplerenone for primary aldosteronism. Hypokalemia and hypertension were corrected with the initiation of eplerenone.

Conclusion: The most common cause of secondary hypertension is primary aldosteronism. DNA damage and oxidative stress due to hyperaldosteronism have been shown to be independent of blood pressure. So attention to early case detection of hyperaldosteronism in hypertensive patients may be an important strategy for the prevention of side effects of high aldosterone level in these patients.
\end{abstract}

\begin{abstract}
Abbreviations: PA: Primary aldosteronism; CT scan: Computed tomography; IHC: Immunohistochemistry; CK: Creatine kinase; CD: Cluster of differentiation; ARR: Aldosterone to renin ratio; HU: Hounsfield unit; RCC: Renal cell carcinoma; FDG PET: Fluorodeoxyglucose positron emission tomography; VMA: Vanillylmandelic acid; ACTH: Adrenocorticotropin hormone; DHEAS: Dehydroepiandrosterone sulfate; TSH: Thyroid stimulating hormone.
\end{abstract}

\section{Introduction}

Primary aldosteronism (PA) is the most common form of secondary hypertension. It can be either cured or treated with surgery or medical therapy. The current estimation of the prevalence of Primary aldosteronism is $5-10 \%$ of all hypertensive patients [1]. Here we described a patient with a history of hypertension and co-incidence of renal cell carcinoma, thyroid nodules, benign prostatic hyperplasia and final diagnosis of primary hyperaldosteronism due to bilateral adrenal mass.

\section{Case presentation}

A 71 year old man with a history of hypertension from 30 years ago, was referred to our endocrine department with uncontrolled hypertension and hypokalemia. He was treated with enalapril 10mg daily and amlodipine $10 \mathrm{mg}$ daily. He had a history of renal cell carcinoma since two years ago that was presented with an incidentally discovered $4.5 \mathrm{~cm}$ right kidney mass and a right kidney cyst in ultrasonography following the evaluation of prostatic hyperplasia. He underwent partial right nephrectomy, resection of right kidney cyst and prostatectomy. Pathological diagnosis was consistent with chromophobe type renal cell carcinoma without any invasion (IHC: CK positive, $c$ kit negative, CD10 positive, vimentin negative). The pathology of the cyst was a cystic papillary renal carcinoma type 1 . One year later, an abdominal CT scan showed biloculate $4 \mathrm{~cm}$ cyst in the mid-portion of the left kidney. Surgery was performed and a renal cell carcinoma type1 was reported.

For evaluation of hypertension and hypokalemia, plasma aldosterone and renin activity were measured after the correction of hypokalemia in our endocrine department. The plasma aldosterone level was $48.2 \mathrm{ng} / \mathrm{dl}$ (reference range, $1-21 \mathrm{ng} / \mathrm{dL}$ ) and the plasma renin activity was $0.1 \mathrm{ng} / \mathrm{ml} / \mathrm{h}$ (reference range, $0.6-1.6 \mathrm{ng} / \mathrm{ml} / \mathrm{h}$ ). The aldosterone to renin ratio (ARR) was 482 . Due to the high ARR ratio

${ }^{\star}$ Correspondence to: Manouchehr Nakhjavani, Endocrinology and Metabolism Research Center (EMRC), Vali-Asr Hospital, Tehran University of Medical Sciences, Tehran, Iran, Tel: +98-21-22049885; Fax: 009821-66434020; E-mail: nakhjavanim@tums.ac.ir

Key words: hypertension, primary hyperaldosteronism, renal cell carcinoma, neoplasia

Received: December 09, 2019; Accepted: December 27, 2019; Published: December 31, 2019 
and presence of hypokalemia, we didn't perform the confirmatory test for hyperaldosteronism. Abdominal CT scan showed thickening and nodularity of both adrenal glands with a maximum size of $10.75 \times 6.79$ $\mathrm{mm}$ in the right adrenal with an HU of 2 and $15.58 \times 12.38 \mathrm{~mm}$ in the left adrenal with $\mathrm{HU}$ of 7 (Figure 1). In a retrospective analysis of the first abdominal CT scan in 2014, there was the enlargement of both adrenal glands which was not noticed.

Results of other laboratory tests were midnight salivary cortisol of $0.06 \mu \mathrm{g} / \mathrm{dl}$ (reference range, $<0.13 \mu \mathrm{g} / \mathrm{dl}$ ), ACTH: $16.2 \mathrm{pg} / \mathrm{ml}$ (reference range, $10-60 \mathrm{pg} / \mathrm{mL}$ ), DHEAS: $58.5 \mu \mathrm{g} / \mathrm{dl}$ (reference range, $25-131 \mu \mathrm{g} /$ $\mathrm{dL}$ ), Testosterone: $560 \mathrm{ng} / \mathrm{dl}$ (reference range, 300-1200 ng/dL ), TSH: $2.9 \mu \mathrm{IU} / \mathrm{ml}$ (reference range, 0.3-4.5 $\mu \mathrm{IU} / \mathrm{ml}$ ), Hemoglobin: $15.1 \mathrm{gr} /$ $\mathrm{dl}$ (reference range, 13-18 gr/dl ), Creatinine: $1.8 \mathrm{mg} / \mathrm{dl}$ (reference range, 0.6-1.2 mg/dL ), Sodium: $140 \mathrm{mEq} / \mathrm{L}$ (reference range, 136$142 \mathrm{mEq} / \mathrm{L}$ ), Potassium: $3.1 \mathrm{mEq} / \mathrm{L}$ (reference range, $3.5-5.0 \mathrm{mEq} / \mathrm{L}$ ), Calcium: $9.1 \mathrm{mg} / \mathrm{dl}$ (reference range, $8.6-10.3 \mathrm{mg} / \mathrm{dl}$ ), Phosphorous: 3.2 $\mathrm{mg} / \mathrm{dl}$ (reference range, $2.7-4.5 \mathrm{mg} / \mathrm{dl}$ ), $24 \mathrm{~h}$ urine protein: $1311 \mathrm{mg} / 24 \mathrm{~h}$ (reference range, $<150 \mathrm{mg} / 24 \mathrm{~h}$ ), $24 \mathrm{~h}$ urine metanephrine: $120 \mu \mathrm{g} / 24 \mathrm{~h}$ (reference range, $<400 \mu \mathrm{g} / 24 \mathrm{~h}$ ), urine normetanephrine: $262 \mu \mathrm{g} / 24 \mathrm{~h}$ (reference range, $<900 \mu \mathrm{g} / 24 \mathrm{~h}$ ) and Vanillylmandelic acid (VMA): 10.5 $\mu \mathrm{mol} / 24 \mathrm{~h}$ (reference range, $<13.5 \mu \mathrm{mol} / 24 \mathrm{~h}$ ).

Moreover, thyroid nodules were found in physical examination. Thyroid ultrasonography showed an $11.5 \times 5.5 \mathrm{~mm}$ isoechoic nodule with a regular margin and without calcification and with peripheral vascularity in the isthmus, a $19 \times 15 \times 12 \mathrm{~mm}$ isoechoic nodule with a regular margin, without calcification and with peripheral vascularity in the left lobe and a $6 \times 6 \mathrm{~mm}$ isoechoic nodule in the right lobe. Fine needle aspiration biopsy of thyroid nodules was negative for malignancy.

FDG PET CT was performed for further evaluation and showed foci of metabolically active lesions in both kidney, Thyroid nodules without FDG uptake, Metabolically active lymph nodes in AP window and right hilar region in the chest and enlarged adrenal glands with mild FDG uptake that were more likely benign in nature.

Regarding renal insufficiency, adrenal Venus sampling was not performed. Due to bilateral adrenal involvement eplerenone was prescribed in a dose of $50 \mathrm{mg}$ daily. Hypokalemia and hypertension were corrected with the initiation of eplerenone and the doses of

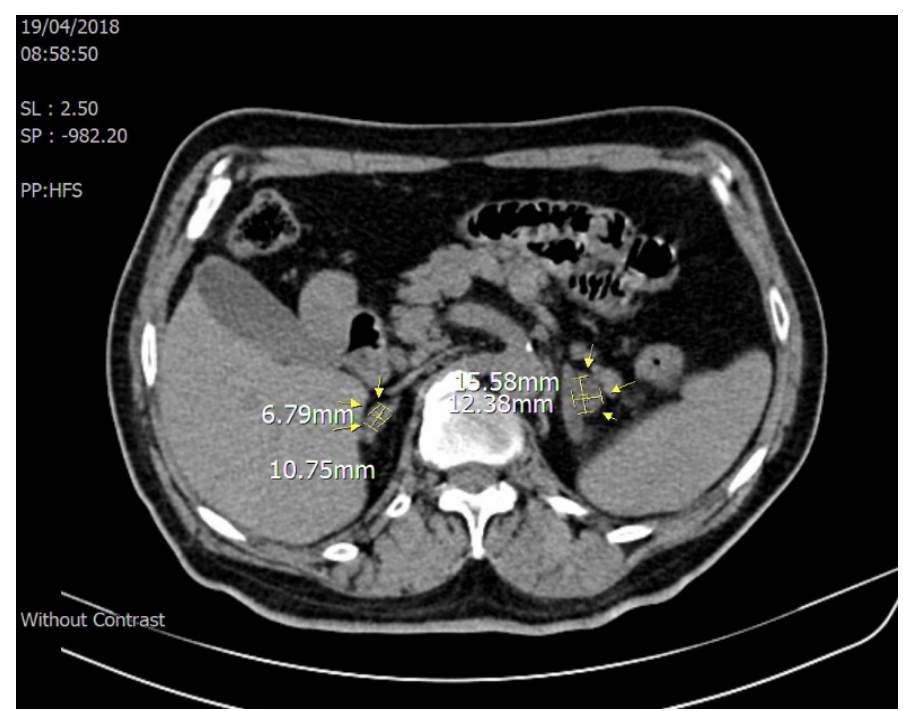

Figure 1. Bilateral adrenal masses with $\mathrm{HU}$ of 2 in the left side and $\mathrm{HU}$ of 7 in the right side in the abdominal computed tomography after surgical resection of renal cell carcinoma antihypertensive drugs were reduced and Proteinuria decreased from $1311 \mathrm{mg}$ to $200 \mathrm{mg}$ per $24 \mathrm{~h}$.

\section{Discussion}

Here we described a 71year old man with a history of hypertension since 30 years ago, presented with a malignant tumor including bilateral renal cell carcinoma and multiple benign neoplasms including benign prostatic hyperplasia, multinodular goiter and bilateral adrenal masses with the final diagnosis of primary aldosteronism. This is a rare association between renal cell carcinoma, multiple benign neoplasms and primary aldosteronism due to bilateral adrenal mass.

In the MEPHISTO study, in 335 patients with confirmed primary aldosteronism, five patients had renal cell carcinoma (RCC). Four of them had unilateral aldosterone producing adenoma and all of them had hypokalemia. Median plasma aldosterone level was $469 \mathrm{ng} / \mathrm{l}$ and there was an association between aldosterone level and the prevalence of RCC. Tumor histology of three patients were clear cell carcinomas, one of them was papillary, and one as chromophobe RCC. There were renal cysts in four of the five patients, before the diagnosis of the RCC [2]. Our patient had bilateral adrenal masses and hypokalemia. There was renal cyst before the diagnosis of RCC and the histology was chromophobe type renal cell carcinoma.

Hypertension is a risk factor for renal cell carcinoma [3]. Also, oxidative stress has a role in the pathogenesis of cancer development [4] and Oxidative stress rise in primary aldosteronism [5]. Aldosterone can lead to DNA damage and activation of transcription factor nuclear factor-KB (NF-KB) [6]. Transcription factor nuclear factor-KB has the main role in the regulation of immunity, inflammation, cell proliferation, and apoptosis and plays a key role in malignant transformation, the progression of tumors and chemoresistance of cancers [7]. The oxidantmediated genotoxic effects of aldosterone and long-term activation of $\mathrm{NF}-\mathrm{KB}$ as a potentially oncogenic cell signal could contribute to the higher incidence of renal cancer in patients with hypertension [6]. Also, the upregulation of the proto-oncogene K-RAS by aldosterone may play a role in the development and growth of renal cell carcinoma [8].

In summary, possible mechanisms for this association of primary aldosteronism and RCC are hypertension, oxidative stress, DNA damage, activation of transcription factor nuclear factor-KB and upregulation of the proto-oncogene K-RAS.

\section{Conclusion}

The most common cause of secondary hypertension is primary aldosteronism. DNA damage and oxidative stress due to hyperaldosteronism have been shown to be independent of blood pressure [9]. So, attention to early case detection of hyperaldosteronism in hypertensive patients may be an important strategy for the prevention of side effects of high aldosterone level in these patients.

\section{Conflict of interest}

The authors have declared that no Conflict of interest exists.

\section{References}

1. Young Jr WF (2019) Diagnosis and treatment of primary aldosteronism: practical clinical perspectives. Journal of Internal Medicine 285: 126-148.

2. Lang K, Weber K, Quinkler M, Dietz AS, Wallaschofski H, et al. (2016) Prevalence of malignancies in patients with primary aldosteronism. J Clin Endocrinol Metab 101: 1656-1663.

3. Colt JS, Schwartz K, Graubard BI, Davis F, Ruterbusch J, et al. (2011) Hypertension and risk of renal cell carcinoma among white and black Americans. Epidemiology 22: 797. 
4. Sosa V, Moliné T, Somoza R, Paciucci R, Kondoh H, et al. (2013) Oxidative stress and cancer: an overview. Ageing Res Rev 12: 376-390.

5. Petramala L, Pignatelli P, Carnevale R, Zinnamosca L, Marinelli C, et al. (2014) Oxidative stress in patients affected by primary aldosteronism. J Hypertens 32 : 20222029.

6. Queisser N, Oteiza PI, Stopper H, Oli RG, Schupp N (2011) Aldosterone induces oxidative stress, oxidative DNA damage and NF-kB-activation in kidney tubule cells. Mol Carcinog 50: 123-135.
7. Papa S, Bubici C, Zazzeroni F, Pham CG, Kuntzen C, et al. (2006) The NF-кBmediated control of the JNK cascade in the antagonism of programmed cell death in health and disease. Cell Death Differ 13: 712.

8. King S, Bray S, Galbraith S, Christie L, Fleming S (2014) Evidence for aldosteronedependent growth of renal cell carcinoma. Int J Exp Pathol 95: 244-250.

9. Queisser N, Amann K, Hey V, Habib SL, Schupp N (2013) Blood pressure has only minor influence on aldosterone-induced oxidative stress and DNA damage in vivo. Free Radic Biol Med 54: 17-25.

Copyright: (C2019 Rabizadeh S. This is an open-access article distributed under the terms of the Creative Commons Attribution License, which permits unrestricted use, distribution, and reproduction in any medium, provided the original author and source are credited. 